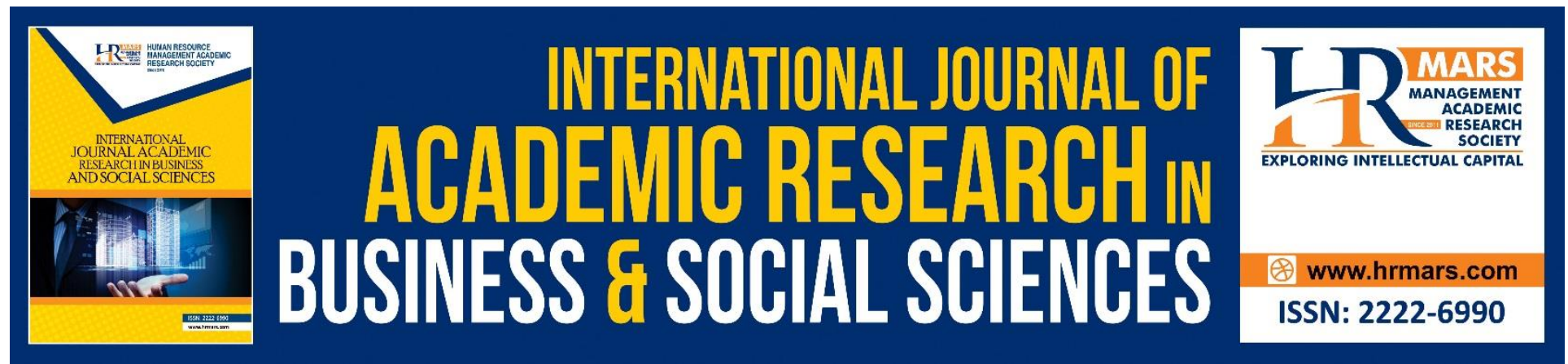

\title{
Influence of Performance Management Systems on Employee Productivity in County Referral Hospitals of Kiambu County
}

Carolyn Akinyi Owino, Musa Oluoch, Fredrick Kimemia

To Link this Article http //dx.doi.org/10.6007/IJARBSS/v9-i3/5799 $\quad$ DOI 10.6007/IJARBSS/v9-i3/5799

Received 21 Jan 2019, Revised 21 Feb 2019, Accepted 1 March 2019

Published Online 21 March 2019

In-Text Citation (Owino, Oluoch, \& Kimemia, 2019)

To Cite this Article Owino, C. A., Oluoch, M., \& Kimemia, F. (2019). Influence of Performance Management Systems on Employee Productivity in County Referral Hospitals of Kiambu County. International Journal of Academic Research Business and Social Sciences, 9(3), 1320-1336.

\section{Copyright (C) 2019 The Author(s)}

Published by Human Resource Management Academic Research Society (www.hrmars.com)

This article is published under the Creative Commons Attribution (CC BY 4.0) license. Anyone may reproduce, distribute, translate and create derivative works of this article (for both commercial and non-commercial purposes), subject to full attribution to the original publication and authors. The full terms of this license may be seen at http

//creativecommons.org/licences/by/4.0/legalcode

\section{Vol. 9, No. 3, 2019, Pg. 1320 - 1336}

Full Terms \& Conditions of access and use can be found at http//hrmars.com/index.php/pages/detail/publication-ethics 


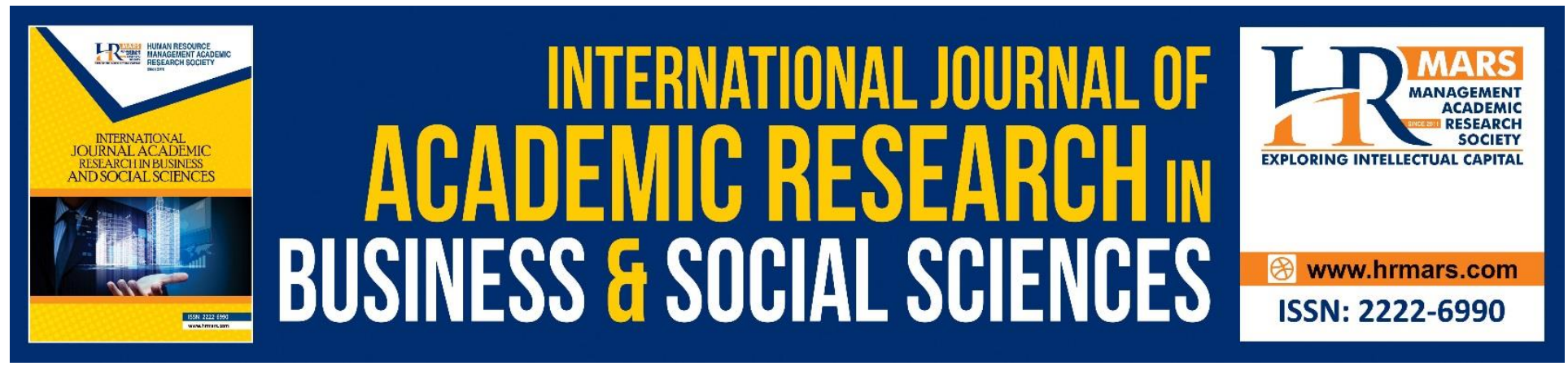

\title{
Influence of Performance Management Systems on Employee Productivity in County Referral Hospitals of Kiambu County
}

\author{
Carolyn Akinyi Owino \\ Department of Health Systems Management, Kenya Methodist University, Nairobi, Kenya \\ Email:muhcarol@gmail.com

\section{Musa Oluoch} \\ Department of Health Systems Management, Kenya Methodist University, Nairobi \\ Email: musadot123@gmail.com

\section{Fredrick Kimemia}

\section{Department of Health Systems Management, Kenya Methodist University, Nairobi} \\ Email: kimemiafred@yahoo.com
}

\begin{abstract}
This was a descriptive cross-sectional study on the influence of performance management system on employee productivity in county referral hospitals of Kiambu County. Aspects that were investigated included planning, appraisal, feedback, and reward. Proportionate stratified sampling was used to get three hundred and ten respondents. The research instrument was a questionnaire and Statistical Package for Social Sciences version 22 was used to describe data and determine the extent of the relationships. All the four variables had a significant and positive influence on employee productivity. That is, planning $\left(r=.544^{* *}, P=.000\right)$; appraisal $\left(r=.641^{* *}, P=.000\right)$; feedback $\left(r=.700^{* *}, P .000\right)$ and finally reward $\left(r=.673^{* *} P=.000\right)$. Regression analysis indicated that planning $\left(\beta_{1}=.130, P=.159\right)$ and appraisal $\left(\beta_{2}=.129, P=.203\right)$, were statistically insignificant in predicting employee productivity. However, feedback $\left(\beta_{3}=.302, P=.002\right)$, and reward $\left(\beta_{4}=.387, P=.000\right)$ were the strongest predictors of employee productivity when all the four variables were combined. Recommendations included setting of clear, realistic goals as a team, having regular review discussions on performance with employees, providing regular constructive feedback and reward system should be linked to the results of the appraisal which is just and fair.

Keywords: Performance Management Systems, County Referral Facilities, Employee Productivity, Feedback, Rewards.
\end{abstract}




\section{Background}

In Korea, Kim and Kong (2015) report that there are few researches on influence of PMS in health care sector. A study by Rakaogale (2012) in Limpopo show that performance management cycle has been reduced to a momentary event at the end of the reporting period therefore giving a false reflection of the state of affairs. Since the introduction of PMS by GoK in 2004 no research has been conducted to determine its influence on employee productivity in public health care facilities.

During informal interactions with staffs at the Thika county referral facility, the researcher noted that some of them assumed that performance management involved only target setting and performance appraisals and the whole cycle was not addressed. In addition, the schedule for performance appraisal was not adhered to and some of them viewed it as a bureaucratic activity that was a waste of their time. Furthermore, the researcher also noted that prospects for career progression were limited. This raises the question on the influence of performance management systems on employee productivity. It is against this background that the researcher wants to determine the influence of performance management system on employee productivity in the county referral facilities of Kiambu. The research questions are does performance planning and appraisal report influence employee productivity in county referral facilities of Kiambu County? Is employee productivity influenced by giving feedback and reward systems? Most health care workers equate performance management system with performance appraisal or performance review (Nayak et. al., 2014). PMS however involves planning, feedback, and rewards in addition to appraisals (Krishnan, 2017). Focusing only on performance appraisal leads to misrepresentation and under-valuing the benefits of performance management systems. It will be particularly beneficial to the county government and the country by providing the first empirical evidence on whether performance management systems for public health facilities is a feasible process for improving employee productivity and hence quality of care, thereby improving health outcomes.

This was a timely research considering the achievement of SDGs and the GoK quest to improve service delivery in public health facilities in the country which have been devolved. The information gathered will help to inform policies at county and national levels.

The findings will also benefit Gatundu, Thika and Kiambu county referral facility employees and other stakeholders to understand the gaps in PMS and strengths. Recommendations will lead to better understanding and appreciation of PMS and its contribution to employee productivity.

These findings will also add immensely to the body of knowledge in $\mathrm{HRH}$ considering that the health worker is responsible for steering the entire health sector. The researcher hopes that the information presented in this paper will encourage furthermore rigorous research on this increasingly popular health care reform, which will add to the body of knowledge concerning its impact.

\section{Literature Review}

The public service delivers its objectives through human resources and therefore it's paramount that proper mechanisms are available so that human resources can be accountable for their actions and also supported to maximize their potentials. Performance management is often taken to be crucial in improved service delivery. It was assumed for a while that performance in the public sector was impossible to measure (Boland and Fowler (2000) cited by Lewis (2015). Currently performance 
management has become perhaps the most widely pursued public sector reform of recent decades (Bevan, 2004).

There is a general agreement that there are numerous benefits of performance management but there's scanty literature to guide practice in health care (Health policy 2006). According to Smith et. al (2009) the main function of performance management is monitoring, evaluation and communicating the extent to which health systems and its aspects meet key objectives.

Performance management is able to bring all employees to work towards a common goal. This ensures delivery of results because all efforts are geared towards achieving a common objective (Balogun, 2003)..

Employee performances management is an exercise where all employees have a shared understanding concerning the goals of the organization and how to achieve the objectives as captured by Weiss et al (1997) cited by Korir et. al (2015). Organizational objectives are well aligned with the employees agreed targets, skills and the delivery of results. The emphasis is on continual improvement, learning and development in order to create a high-performance workforce while achieving the overall organization strategy. When performance management system is implemented accurately, linking specific objectives to the strategic and operational plans, institutional performance outcomes will more likely increase very steadily.

Performance management system helps to breakdown extensive departmental strategic plans into clear achievable performance milestones for each individual. This easily provides a basis for continual monitoring of individual performance, the giving of feedback and the execution of measures to improve performance (Armstrong, 2009).

Armstrong (2004) suggests the following action plan for effective performance management development of the strategic plan which is linked to an annual action plan, ensuring all employees are involved in the whole process to increase buy-in, and regular on job training. The organization must plan for a training program that ensures employees are involved in decision making. In addition, managers must acknowledge that effective communication between them and staff is an effective tool for performance. Non-monetary incentive system may also be introduced along monetary incentives to encourage improved employee productivity. Performance management is intended to enhance job satisfaction for the staffs with the hope that their satisfaction would lead to improved work productivity.

\section{Global Scenario of Influence of PMS on Employee Productivity}

In England, the National Health Services made up of over 8,300 separate organizations and a staffing of over 1.3 million uses Public Service Agreements which are incorporated into performance based agreements. It has been rated as the fairest and most patient centered health system in the world with the highest customer satisfaction levels in the world Department of Health UK (2016). A survey was conducted by the Performance Management Institute of Australia of Australian employees' concerning their attitudes towards PMS for approximately 450 employees. The research found out that slightly above half of them received performance reviews once a year and the other half were 
not reviewed. The employees were also not involved in target setting and therefore leading to dissatisfaction during reviews (Nankervis, 2006).

In SSA, Uganda for example, has experiences in weak PMS of the health worker. Lutwama et al (2013) in his study unearthed several gaps in the implementation of PMS in the Ugandan health sector. They included absence of setting targets and planning, unclear indicators for measuring performance, irregular performance appraisal and limited staff training and development. A study done by Dieleman (2006) indicated that PMS had not been ideally implemented in Mali, as job descriptions were lacking or were inappropriate, a very low percentage (13\%) were appraised and training needs were not analyzed. Employees at Father Smangaliso Mkhatswa center in South Africa of different hierarchy view PMS differently. Those of lower hierarchy view PMS as means of increasing their income and those of the higher hierarchy view PMS as an instrument to control and discipline subordinates. Halo effect is dominant where supervisors show favoritism to certain subordinates. They are, however, aware that PMS is a tool to improve service delivery by addressing poor performance through human resource development programmes and rewarding good performance (Paile J. 2012).

According to GoK (2007), the public sector had invariably fallen below expectations due to several factors that include frequent political interferences, poor leadership and management and nonperforming employees leading to poor employee productivity. Following the adoption of a new constitution in August 2010 in Kenya a new governance framework with a national government and 47 counties was introduced. The former form of governance was highly centralized and it led to political and economic disempowerment and unequal distribution of resources (World Bank, 2012). In 2015 annual conference report for devolution of health care services in Kenya, there were several challenges identified in HRH such as salary disparities, uncoordinated training, delay of promotions and limited career progression. The delegates suggested that these challenges could be addressed by use of performance management systems (MOH, 2016).

\section{Influence of Performance Planning on Employee Productivity}

Performance planning is the first most important component of the performance management process since it's the basis of performance appraisals. It is during this time that employees decide collectively on the targets and identify the key performance areas which can be attained over a period of one year. This is usually within the performance budget and is finalized after a mutual agreement between the reporting officer and the employee (Markus, 2004). The performance agreements puts in perspective expectations while at the same time creates a common point of reference for senior management, staff and their supervisors in the entire PMS process. The performance agreements clearly states the standards of performance which a government requires public officials, or the management of state owned or public agencies or ministries to meet over a period of time (Hope, 2011). Olusanya et. al (2012) agrees that effective planning in PMS positively contributes to improved employee productivity in an institution. 
In Kenya, institutions are required to set targets in which fall into the four categories in the following descending order; financial indicators, non-financial indicators, operational indicators and finally dynamics indicators. Most targets in public institutions are usually the same in most categories for operational indicators which are specific in accordance to the mandate of the institutions. Using a departmental plan, institutions should develop a work plan, which indicates primary activities to be accomplished by the end of the financial year. The work plans are used as the basis for evaluation at the end of every quarter (Performance Contracts Steering Committee, 2004). Existing policy documents, that is, NHSSPs, Medium Term Plan 2013-2017, Vision 2030 and institutions' strategic plan are used to prepare work plans. The performance contracts are then signed as a sign of accountability and to show ownership by the relevant senior management authority and the institutions accounting officers. In the case of the ministry of health the cabinet to the secretary and the principal secretary signs (Ndubai, 2011).

Employees need resources during their planning stage. Nielsen et al (2017) states that resources are "anything perceived by the individual to help attain his or her goals". Resources are categorized into four levels in the work place, and they help employees achieve their work task goals in four areas. These areas included personal characteristics such as self-efficacy which enable an individual to perform well (Xanthopoulou et al (2007), social context associated with interpersonal relationships, leadership characteristics and organizational resources. Planning was associated with increased performance in companies according to a study by Gibson et al (2005). Draft (1998) cited by Nassazi (2013) says that performance management process allows employees to get engaged in planning for the company, and therefore participates by having an active role in the entire process and this translates to increased productivity.

\section{Influence of Performance Feedback on Employee Productivity}

According to Mathauer and Imhoff to (2006) health care workers stated that they rarely receive any personal feedback from their supervisors. The feedback they receive concentrates on few shortcomings or technical aspects of service provision. It does not look at the perspective of the health worker as a person.

They also cited that personal feedback is more common in faith based organizations and private facilities than in public facilities. Performance management promotes employee's identity and a sense of belonging delegating responsibility providing feedback recognizing and valuing employee success.

For a performance management process to be considered successfully then the feedback has to prompt and constructive and this should be in line with the set targets. When prompt and constructive feedback is shared to employees on concerning their progress towards the set goals, then employee productivity will surely improve. Employees need to be informed promptly if they are achieving their targets. Davis (2011) states that any performance feedback system must furnish employees promptly to ensure they are satisfied with their process. 
INTERNATIONAL JOURNAL OF ACADEMIC RESEARCH IN BUSINESS AND SOCIAL SCIENCES Vol. 9, No. 3, March, 2019, E-ISSN: 222 2-6990 @ 2019 HRMARS

According to Obwaya (2010) feedback corrects repetition of mistakes and keeps staff focused on what is required of them. She also noted that public service culture inhibited free interaction between senior management and employees, and the bureaucratic processes were a barrier to flow of information, making it difficult to give feedback to staff promptly as required.

\section{Objective Performance Appraisal System on Employee Productivity}

The performance appraisal system is one of the components of Performance Management System in the public service as stated by Armstrong (2009). Individual employee work plans are integrated into all the other components of the performance management systems, that is, planning, execution of set targets, performance feedback and evaluation (PSCK, 2015).

The GoK sets the appraisal period for one year, beginning from 1st July to 30th June of the following year and it reflects an employee's overall year's performance. There are two reviews in that financial year, that is, on-going and mid-year performance review. For the on-going performance appraisal it takes place throughout the performance period and achievements are recorded and tracked in the appraisee's personal file. During the mid-year performance review the supervisor sits with appraisee to review the progress made by the appraisee and the initial goals that were set at the beginning are used to measure how far the appraisee has reached in terms of meeting the targets (GoK, 2008). This mandatory mid-year performance review discussions focus on the achievements, constraints and how to overcome them even if it means reviewing the initial set targets which may not be achievable due to some constraints which had not been anticipated (GoK, 2008).

The Public Service Commission of Kenya (PSCK) uses performance appraisal and improvement to reinforce support supervision in institutions and improve service delivery for its citizens. One of the many purposes of performance appraisal is to motivate, audit, evaluate, identify training needs, and develop an individual and plan for future. Due to its perceived usefulness, performance appraisal is currently seen as an open process where teams set and discuss openly objectives and targets for the purposes of aligning individuals' goals and organizational goals (Kobia, 2006). Armstrong (2006) in his perspective described the role of performance appraisal in any organization as a very useful tool for describing what needs to be done by employees to meet targets and to have challenging work. This ensures that the supervisors are able to maximize the employees' skill, talents and ensure better use of other resources in the organization.

\section{Linking Reward to Measurable Performance}

Armstrong (2009) states that the role reward system in PMS cannot be underestimated. Rewards contribute to improving performance and productivity through means such as recognition, personal development of employees, informing pay decisions and job designs. In the Kenyan public sector scenario, PMS uses rewards and sanctions to encourage employees to provide quality services (GoK, 2010). Performance managers may reward an individual or a team either in cash or in kind. PMS is one major way to ensure that good performance rewarded since it ensures that competent staffs are motivated in their jobs (Maycock, 2015). 
According to Oluwabusola (2015), performance management is not used as a basis for promotional schemes rather, length of service in many public sectors. Seniority based pay leads to unequal pay since it does not recognize employees who contribute more than others and should be compensated accordingly. Health care managers are under pressure to reduce operating costs, improve employee productivity, increase patient safety, outcome and experiences. In order to achieve these outcomes, they have turned to performance management so as to stimulate innovation in employees as a way to survive and succeed in this new healthcare environment. One of the main objectives of PMS is to ensure that as employees are achieving organizational goals, they are also achieving their individual goals and motivated employees are key performance management (FSR, 2014). In Kenya, one of the ways used by the GoK to motivate and recognize outstanding public servants was the use of performance management. Flynn (1988) as quoted by Danish (2010) recognizes that rewards and recognition boosts employees' morale, keeps them in high spirits and they showed that there was a direct link between performance and motivation of employees.

\section{Employee Productivity}

Armstrong (2006) describes productivity in terms of outputs relatively to inputs either per person or per system with reference to a specific point of time, that is, the amount of goods and services produced relative to the resources used as described in a work description. Productivity is considered based on the interrelationship with performance and profitability.

Human resource is one of the most important resources that affect productivity in any organization. A motivated, dedicated and committed employee will perform better and institutions are encouraged to value their human resource since it is only manpower that makes the difference in the performance. Any organization should strive to maintain their human resources by ensuring factors that affect productivity are constantly monitored. These factors may include, technology, training, policies, opportunities for upward career development and the attitude of management. These factors of productivity, if well harnessed, create interest in employees to work and give their best. They cause them to be innovative and lets the employees take responsibility for their performance. This in turn reduces time wasted on reworks, accidents and wastes. Consequently, there is improved quality and more output and more productivity.

Koretz (1995) stated that there are four productivity factors "inadequate supervision and employee involvement in decision-making, too much work, and insufficient rewards and chances to advance".

In Ghana, Boateng (2014) found that conducting performance appraisals have positive effects on employee efficiency, effectiveness, motivation and overall performance. A study published in international journal of research in 2013 study proved that training for both new and existing employees actually improves performance and overall efficiency (Uma 2013). Berg et al. (2013) further indicates that to foster a healthy communicative culture in an organization, there must be clear parameters for success, constructive feedback and giving employees challenging, meaningful work.

Employee creativity greatly influences employee productivity since they are able to come up with novel ideas that are beneficial to the organization (Gong et al 2013). These innovative ideas include 
developing new procedures or processes for completing tasks, or pinpointing products or services that increase customer satisfaction (Zhou, 1998; Zhou \& Shalley, 2003). Innovative ideas may also include reviewing existing procedures or processes to enhance institutional efficiency and effectiveness. When employees use creative ideas to improve their work processes, it results in the improvement of the whole institution (Shalley et al., 2004).

Employee performance can be viewed in terms of outcomes or behavior (Armstrong 2000) and can be measured against the performance standards set by the organization (Kenney et al, 1992). These measures include productivity, effectiveness, efficiency, profitability and quality (Ahuja, 1992). While efficiency is producing the desired outcomes by use of minimal resources effectiveness is the potential of an employee to meet the set targets (Stoner 1996).

According to Armstrong (2012), employee performance is an a participatory activity in an instituion. The employee is usually involved and valued in the organizations vision and mission. The employee is very clear on what the organization seeks to achieve and is allowed to voice his/her ideas on the day to day business and these are ideas are taken into consideration. They employee keeps their focus on what is to be achieved, is able to be empowered with resources and skill, receives adequate, prompt and constructive feedback. In addition, whenever they surpass their targets or improve processes, they are appreciated, recognized and possibly rewarded. (MaCleod 2018).

Locke (1976) defined job satisfaction as "a pleasurable or positive emotional state resulting from the appraisal of one's job and job experiences". Armstrong et. al (2017) states that job satisfaction is a precursor to employee performance and it is interrelated with job involvement and organizational commitment.

Armstrong (2009) noted that when an employee find tasks are interesting and challenging, and they are given responsibility and control over resources then it influences job performance. For work to be challenging, the scope has to be broad, the responsibility high and the work load high. This will more likely increase performance since it creates room for personal growth and accomplishment

When employees exercise autonomy in scheduling their work and determining procedures, they get a sense of ownership and control over their outcomes. This means that as employees exercise authority in decision making, it makes their work enjoyable and it gives them job satisfaction. For the employees to be able to exercise autonomy, they must have clear set goals, constant, prompt and constructive feedback for improvement so that they know what they are doing wrong and how might they improve and areas in which they are excelling. Mone et al , (2011) quoted by Hughes (2013) emphasizes the significance of conducting mandatory midyear and year-end appraisals to provide feedback and recognition to employees

Hughes (2013), states that employees must be given an opportunity to grow and progress in their careers. An employee who sees an opportunity for growth, career development through acquiring 
INTERNATIONAL JOURNAL OF ACADEMIC RESEARCH IN BUSINESS AND SOCIAL SCIENCES

Vol. 9, No. 3, March, 2019, E-ISSN: 222 2-6990 @ 2019 HRMARS

new skills and knowledge and promotion works harder and in turn this increases productivity. These are viewed by employees as a personal investment in their time while in the organization.

Macey and Schneider (2008) as quoted by Armstrong (2017) argued that leaders with clear goals, who are fair, and regularly recognize good performance, will have positive effects on employee productivity since they instill a sense of attachment to the job.

\section{Methodology}

The research adopted a descriptive cross-sectional study design to investigate the effect of performance management system on employee productivity in county referral hospitals of Kiambu County. This study design assisted the researcher to get data on all variables at once and it was quick and easy to conduct since there were no long periods of follow up. The study was carried out in Kiambu County, one of the forty-seven counties under the constitution of Kenya. Among the public facilities, there are three county referral facilities in Kiambu County namely Gatundu, Kiambu and Thika County referral hospitals. There are three county referral facilities within Kiambu County that is, Gatundu, Kiambu and Thika. Respondents were drawn from these facilities. To get a representative sample, proportionate stratified sampling was used to get the number of respondents within the different strata to reduce risk of sampling bias and sampling error. Fishers et al (1998) was used to compute the minimum required sample size to three hundred and ten respondents

This study managed to collect quantitative data using a self-administered employee questionnaire and key informant interview guide. . The researcher used the drop-off and pick up method to administer the questionnaires. The respondents were briefed verbally about the study and consent obtained after which they were given two weeks to fill the questionnaires. This was to ensure a high response rate. The questionnaire had two main sections, that is, Section A which consisted of the respondent's demographics which included age bracket, marital status, cadre, level of education years in service. Section B had statements that had a focus on the study variables, that is, performance planning, and appraisal, feedback, reward and employee productivity. The statements were rated on a five-point Likert scale and the responses arranged from 5 strongly agree, 4 agree, 3 Not sure, 2 disagree, 1 strongly disagree.

The key informant interviews were also conducted with the county managers and hospital managers to collect qualitative data. The researcher was able to get input on the aspects of performance management on employee productivity. External validity was ensured through random sampling to reduce selection bias. Validity in this study was ensured by means of restricting the statements in the questionnaire to the concepts of the variables and all the indicators of a specific variable were within the same construct. This was done through pretesting of the questionnaire. Cronbach's alpha coefficient was used to measure reliability and internal consistency. It clearly tells us when items in a set are correlating positively to one another. A coefficient of 0.70 or more suggests a high degree of data reliability (Mbwesa, 2006). Cronbach's Alpha values for each were all above 0.7. This implies that the instrument had a high reliability co-efficient. The findings for each variable in this study are given by the Pearson's Rho ( $r$ ) and its corresponding $p$-value. If the $p$-value corresponding to a given Rho is less than 0.05 , then the relationship or influence of the independent variable on the dependent variable is statistically significant and vice versa is also true for $p$-values greater than 0.05 . 
INTERNATIONAL JOURNAL OF ACADEMIC RESEARCH IN BUSINESS AND SOCIAL SCIENCES

Vol. 9, No. 3, March, 2019, E-ISSN: 222 2-6990 @ 2019 HRMARS

\section{Analysis and Findings}

The demographic characteristics of the respondents revealed that there were more female respondents who accounted for $59.5 \%$ of the sample compared to male respondents who accounted for $40.5 \%$. Furthermore majority of the respondents were aged between $31-40$ years at $41 \%$ and only $9 \%$ of the respondents were aged above $50 \% .49 .5 \%$ of the respondents were diploma holders and only $0.5 \%$ were PhD. Holders. Nurses at $47.4 \%$ made the majority of the respondents.

\section{Influence of Performance Planning on Employee Productivity Table 4.1 \\ Descriptive Statistics Performance Planning variable}

\begin{tabular}{|c|c|c|c|}
\hline & $\underline{N}$ & Mean & $\underline{\text { Std. Deviation }}$ \\
\hline I'm familiar with the mission and vision of this facility. & 222 & 3.8063 & 1.29508 \\
\hline I have a clear job description. & 222 & 4.3059 & 1.01931 \\
\hline Clear and realistic targets and goals are set as a team. & 222 & 3.6991 & 1.24534 \\
\hline $\begin{array}{l}\text { I understand the purpose of setting targets in } \\
\text { performance management system. }\end{array}$ & 222 & 4.0225 & 1.17840 \\
\hline $\begin{array}{l}\text { I'm empowered with adequate resources to implement } \\
\text { the set plans. }\end{array}$ & 222 & 2.9455 & 1.39691 \\
\hline $\begin{array}{l}\text { Performance reviews are scheduled at the beginning of } \\
\text { the financial year. }\end{array}$ & 222 & 3.4194 & 1.33132 \\
\hline I have a clear work plan that specifies success criteria. & 222 & 3.5727 & 1.23835 \\
\hline Valid N (listwise) & 222 & & \\
\hline
\end{tabular}

According to the study findings in Table 4.1, the respondents agreed with the statements that they were familiar with the mission and vision of their facility (mean score 3.80), they had a clear job description with a mean score of 4.31, clear and realistic targets and goals were set as a team (mean score, 3.70), they understood the purpose of setting targets (mean score, 4.02), performance reviews were scheduled at the beginning of the financial year (mean score of 3.42) and they have a clear work plan that specifies success criteria with a mean score of 3.57 .

These findings reveal that most of the staffs are familiar with the component of planning in terms of what they need to know or do to achieve their targets. It can be deduced that since targets must be aligned with the overall goals of the country's vision 2030, the staffs are well supported by the management team and therefore the familiarity with this component.

These results are consistent with the findings of employees of Kenyan telecommunications centers by Cherono (2015) where $68 \%$ of the respondents agreed that performance planning was undertaken in the organization, data gathering (54\%) and annual reviews (72\%). These findings are also consistent with the Locke (1968) in his goal setting theory that specific goals result in greater effort than do more general goals and difficult goals (when accepted) result in greater effort than do easier goals. The goal setting theory also stated that participation enhances goal commitment by helping organization members to understand the goals and ensures the goals are not unreasonable. 
INTERNATIONAL JOURNAL OF ACADEMIC RESEARCH IN BUSINESS AND SOCIAL SCIENCES Vol. 9, No. 3, March, 2019, E-ISSN: 222 2-6990 @ 2019 HRMARS

The respondents, however, disagreed that they were empowered with adequate resources to implement their set plans with a mean score of 2.95. Resources are defined as "anything perceived by the individual to help attain his or her goals" ( Nielesen 2017). From the descriptive statistics of cadre in comparison to the recommended staffing guidelines by $\mathrm{MOH}$ (2014), there is critical shortage of staffs in these county referral hospitals. One of the resources they could be limited with is human resource. This is also reflected in the statement below by one of the key informants form the county management team;

"One of the main challenges during the planning stage is lack of enough staffs. You find that there are a lot of patients to be attended let's say in outpatient but there's only one clinician".

The interpretation of these findings is that planning is critical component of performance management system. Part of the planning includes clear mission and vision which then employees are able to set goals as a team. Draft (1998) cited by Nassazi (2013) says that performance management process ensures all employees are involved in planning for the institution, and this goes a long way in motivating them as they feel motivated to improve productivity. It is easier to monitor work deficiencies during planning and especially when all employees are involved and these are easily addressed.

\section{Influence of performance appraisal on employee productivity}

Table 4.2

Descriptive Statistics Performance Appraisal Variable

\begin{tabular}{|c|c|c|c|}
\hline & $\underline{N}$ & Mean & $\underline{\text { Std. Deviation }}$ \\
\hline I'm familiar with the performance appraisal guidelines & 222 & 3.8198 & 1.21973 \\
\hline $\begin{array}{l}\text { My performance is evaluated based on my job } \\
\text { description }\end{array}$ & 222 & 3.8100 & 1.30735 \\
\hline I'm satisfied with the performance appraisal process & 222 & 3.4128 & 1.31430 \\
\hline There is regular performance review & 222 & 3.2706 & 1.32511 \\
\hline $\begin{array}{l}\text { My supervisor takes my performance appraisal discussion } \\
\text { seriously }\end{array}$ & 222 & 3.4661 & 1.38989 \\
\hline $\begin{array}{l}\text { Performance appraisal process helps me to find out } \\
\text { about my level of performance }\end{array}$ & 222 & 3.6364 & 1.30840 \\
\hline $\begin{array}{l}\text { I get a chance to discuss my aspirations and work } \\
\text { challenges during the performance appraisal discussion }\end{array}$ & 222 & 3.2890 & 1.36242 \\
\hline Valid N (listwise) & 222 & & \\
\hline
\end{tabular}

According to the study findings in Table 4.2 concerning performance appraisal, the respondents agreed with the statements that they were familiar with the performance appraisal guidelines (mean score 3.82), their performance was evaluated based on their job description (mean score 3.81) and the process of performance appraisal helps them to find out about their level of performance (mean score 3.63). The respondents also agreed that their supervisors take the performance appraisal 
discussion seriously mean score (3.47) and they were satisfied with the performance appraisal process (mean score 3.41). All civil servants must fill the GP 247 PAS forms every financial year as a requirement by the Public Service Commission of Kenya. The mandatory discussions, as Mid-year performance review sessions are centered on achievements, constraints experienced and possibility of modifying the initial targets (GoK, 2008). This could explain why the respondents were familiar with the appraisal guidelines and that they were evaluated based on their job descriptions.

The respondents, however, disagreed on the statement that there were regular performance reviews (mean score 3.27). This is consistent with a study done by Farrel (2013) in Ireland in which performance review schedules were irregular. Mumbi (2013) in a study of a government telecommunications organization in Kenya found that there were no periodical reviews on performance. From the discussion with one of the key informants it emerged that the reviews are done once or twice a year depending on availability of time and the situation at hand. The key informant noted that;

"If there are cases of mishandling of patients then we make sure there's a review of performance. Otherwise we know that staffs are doing their best to achieve their targets"

The respondents also disagreed with the statement that they got a chance to discuss their aspirations and work challenges during the appraisal discussion (mean score 3.29). These findings are consistent with a study done by Njeru (2013) in Kenya Kirinyaga County of civil servants where

$75.7 \%$ of the respondents filled the appraisal forms without any discussion taking place. These findings are also consistent with what was said by one of the key informants.

"These appraisals are done as a formality because we're told we can miss our salaries if they are not documented in our files. Besides we have never seen their impact."

One of the main goals of performance appraisal is to review the past performance of employees. Depending on the outcome of the review, the supervisor together with the employee, can assess the training needs and set targets for future performance The review outcomes to help with disciplinary and other administrative decisions. According to the goal setting theory by Locke and Lotham (2002), organizational members should be able to measure their own progress. This leads to persistence in achievement of goals and hence improved performance.

\section{Influence of feedback on employee productivity}

\section{Table 4.3}

Descriptive Statistics Feedback on Productivity Variable

\begin{tabular}{|llll|}
\hline & $\mathrm{N}$ & Mean & Std. Deviation \\
\cline { 2 - 4 } I receive regular feedback from my supervisor concerning my performance & 222 & 3.1570 & 1.34148 \\
Improvement plans are integrated during the feedback & 222 & 3.2342 & 1.37169 \\
The performance feedback data is used to set priorities in the next working phase & 222 & 3.2818 & 1.35237 \\
The feedback I receive helps me to understand my strengths and weaknesses & 222 & 3.4866 & 1.36576 \\
My feedback is based on actual results or observed behavior & 222 & 3.3982 & 1.29853 \\
I perceive my career growing in this institution & 222 & 3.5207 & 1.28408 \\
There is a policy on training that is followed & 222 & 3.1005 & 1.38105 \\
Valid N (listwise) & 222 & & \\
\hline
\end{tabular}


According to the study findings in Table 4.4 concerning performance feedback, the respondents agreed with the statement that feedback assisted them to understand their strengths and weakness (mean score 3.49). The respondents also perceived career growth in their respective institution (mean score 3.52).

The respondents, however, disagreed on the statement that they receive regular feedback from their supervisors (mean score 3.16). These findings are consistent with a study done by Njeru (2013) in Kenya Kirinyaga County of civil servants where $83.2 \%$ of the respondents never received any feedback on their performance. According to a Gallup study (2015) study in America 37\% of managers stated that they felt uncomfortable to give feedback to their employees, and $69 \%$ of the managers stated they were generally uncomfortable in communicating with their employees. A statement from one of the key informants confirms that staffs are not given feedback regularly.

"We don't have any formal ways of giving feedback. Although we want to create a system so that we can give feedback regularly. We also know most supervisors are not trained to give feedback and sometimes this has worked to demotivate staffs. So sometimes some supervisors avoid it (giving feedback) all together."

The respondents also disagreed on the statement that performance feedback data is used to set priorities in the next working phase (mean score 3.28) and they also disagreed that improvement plans are integrated during the feedback (mean score 3.23). This is consistent with Obwaya (2010) who says feedback corrects repetition of mistakes and keeps staff focused on what is required of them. In Locke's (1968) theory of goal setting, it says that giving feedback results in higher effort than does the lack of feedback.

The respondents also disagreed on the statement that the feedback is based on actual results or observed behavior (mean score 3.39). This is consistent with Cherono (2015) who found in her study that $68 \%$ of the respondents felt that performance appraisals had a low accuracy in representing employee performance. It is also consistent with Kibe (2013), in his study of performance appraisal of public schools in Nakuru County, in which he found that $49 \%$ disagreed that the feedback they received was not in relation to their performance appraisal.

The respondents also disagreed on the statement that there is a policy on training that is followed (mean score 3.10). This agreed with the findings of Barmao et. al. (2009), where $46 \%$ of the respondents were not aware of a training policy in a research to study the impact of training on employee performance. Meenakshi (2012) states that, "organizations carry out performance appraisal as a basis for administrative decisions such as promotion, allocation of financial rewards, employee development and identification of training needs." A statement from one of the key informants stated that they provide trainings for staffs. 
INTERNATIONAL JOURNAL OF ACADEMIC RESEARCH IN BUSINESS AND SOCIAL SCIENCES

Vol. 9, No. 3, March, 2019, E-ISSN: 222 2-6990 @ 2019 HRMARS

"We usually conduct a training needs assessment at the beginning of every financial year and we try to follow it depending on the availability of finances. We also try to identify staffs that will transfer the knowledge they have learnt to enhance performance."

Locke and Lotham (2002) stated that adequate and constructive feedback must be given if challenging goals are to improve employee productivity. They also observed that employees who were given specific feedback concerning their performance improved only on the specific areas that were mentioned but not on other aspects.

\section{Influence of rewards on employee productivity}

Table 4.4

Descriptive Statistics Reward of Productivity Variable

\begin{tabular}{|c|c|c|c|}
\hline & $\underline{\mathrm{N}}$ & Mean & $\frac{\text { Std. }}{\text { Deviation }}$ \\
\hline $\begin{array}{l}\text { There is a formal reward system in line with the performance } \\
\text { appraisal policy in our hospital }\end{array}$ & 222 & 2.5747 & 1.36851 \\
\hline I have been rewarded for surpassing my targets & 222 & 2.0829 & 1.21050 \\
\hline $\begin{array}{l}\text { Promotions and salary increments are based on performance } \\
\text { appraisal }\end{array}$ & 222 & 2.3543 & 1.41900 \\
\hline $\begin{array}{l}\text { The process of rewarding performance in our hospital is fair and } \\
\text { objective }\end{array}$ & 222 & 2.4227 & 1.39419 \\
\hline My job group is fair based on the performance appraisal & 222 & 2.5318 & 1.44421 \\
\hline $\begin{array}{l}\text { The reward system in our hospital is linked to the results of } \\
\text { performance appraisal }\end{array}$ & 222 & 2.4685 & 1.38394 \\
\hline $\begin{array}{l}\text { Employees who work hard are recognized and rewarded in our } \\
\text { hospital }\end{array}$ & 222 & 2.5225 & 1.44802 \\
\hline Valid N (listwise) & 222 & & \\
\hline
\end{tabular}

According to the study findings in Table 4.4 concerning reward of productivity, the respondents disagreed with the statement that there is a formal reward system in line with the appraisal (mean score 2.57). In a study of public school teachers in Ghana by Yamoah (2014), the majority of the respondents (70\%) agreed that study leave with pay and pension benefit were an acceptable reward system for them but housing, transportation, free lunch and sick pay were not a reward program but an entitlement to them as employees. In the case of Kiambu County referral facilities, benefits like housing and transportation allowance are available to workers but in the opinion of the researcher, the respondents could have felt that this was available to them as workers. Therefore, they felt it is not part of a formal reward system.

This concurs with a study by Moriones et. al. (2004) that established that organizations that use seniority based pay rarely offer explicit incentives to their employees as compared to those with no 
wage scheme. He also states that they are usually state owned, older or larger. As earlier stated in the above literature the County Referral facilities of Kiambu County are public hospitals owned by the government and they have a wage scheme in place.

The respondents also disagreed concerning being rewarded for surpassing their target (mean score 2.08). Seniority Based Pay in public sector in African countries is deeply rooted because of the perception of assured job security (Freibert, 1997 as quoted by Oluwabusola (2015). Seniority based pay is therefore viewed as an entitlement where employees are paid based on age regardless of performance (Armstrong, 2004).

The respondents also disagreed that promotions and salary increments are based on performance appraisal (mean score 2.35). The respondents also disagreed that the process of rewarding performance was fair and objective (mean score 2.42). This agrees with a study by Abedi (2004) which showed that $95 \%$ of the respondents felt that appraisal had very minimal impact on their perks and promotion. In another study by Najafi (2010), the researcher indicates that performance appraisal methods in health care system are not effective and have little influence on job improvement. The respondents, however, said that when justice and fairness are observed in appraisal then it would work to improve employee productivity.

It is imperative that employees are not just recognized or paid simply because they have been in an institution longer ,but they must to perform and show a willingness to innovate and improve processes of products, for growth of the institution.

The respondents disagreed that their job groups was fair based on the performance appraisal (mean score 2.53). In another study consisting of nursing employees in the public sector in Macao Chinese society showed that salary did not reflect educational qualifications (Leong, 2014).When a policy was modified, where the basic salary excluded employee benefits such as on shift allowance, there was an increase in salary as compared to the previous wage scheme. This increased employee productivity since most of the nurses felt their workload was commensurate with the pay. Ismail Azman, et al (2011) in a study in Malasyia found that pay for performance and adequacy of pay was positively and statistically significant to job performance.

The respondents in this study disagreed that the reward system is linked to the results of the appraisal (mean score 2.47).They disagreed that employees who work hard are rewarded (mean score 2.52). This agrees with a study done by Oluwabusola (2015), performance management is not used as a basis for promotional schemes rather, length of service in many public sectors. Seniority based pay fails to recognize employees who contribute more than others and this has led to unequal remuneration based on performance especially in the public sector. 
INTERNATIONAL JOURNAL OF ACADEMIC RESEARCH IN BUSINESS AND SOCIAL SCIENCES Vol. 9, No. 3, March, 2019, E-ISSN: 222 2-6990 @ 2019 HRMARS

\section{Employee Productivity and Performance Management}

\section{Table 4.5}

Descriptive Statistics Employee Productivity Variable

\begin{tabular}{|c|c|c|c|}
\hline & $\underline{\mathrm{N}}$ & Mean & $\underline{\text { Std. Deviation }}$ \\
\hline $\begin{array}{l}\text { I have presented a "new" idea to improve patient outcomes, } \\
\text { work processes, etc. }\end{array}$ & 222 & 3.3408 & 1.38541 \\
\hline $\begin{array}{l}\text { My supervisor recognizes staffs who take on challenging } \\
\text { tasks }\end{array}$ & 222 & 3.0807 & 1.47127 \\
\hline I'm able to achieve the targets that we set & 222 & 3.9324 & 3.65106 \\
\hline $\begin{array}{l}\text { There is formal process for submitting new ideas in this } \\
\text { institution }\end{array}$ & 222 & 2.9954 & 1.40607 \\
\hline There is room for being creative in this institution & 222 & 3.2785 & 1.30632 \\
\hline $\begin{array}{l}\text { I have been rewarded/recognized for being presenting a new } \\
\text { idea }\end{array}$ & 222 & 2.4036 & 1.40411 \\
\hline $\begin{array}{l}\text { My suggestion to resolve problems or issues concerning work } \\
\text { processes or patient related issues et cetera are taken into } \\
\text { consideration }\end{array}$ & 222 & 3.0955 & 1.42546 \\
\hline Valid N (listwise) & 222 & & \\
\hline
\end{tabular}

On employee productivity the respondents agreed that they are able to achieve set goals (mean score 3.93).

The respondents disagreed on the statement that they had presented a "new" idea to improve patient outcomes, or work processes (mean score 3.34). This is consistent with the findings of Shikanda et al (2011) where $74 \%$ of the respondents disagreed on being involved in creating new ideas and procedures at work. Kim et al., (2009), noted that with employee creativity, novel ideas greatly contribute to the achievement the set goals. This gives an organization competitive advantage leading to increased productivity.

Respondents also disagreed on the statement that their supervisors recognize staffs who take on challenging tasks (mean score 3.08). This is inconsistent with the findings of Gichohi (2014) in his study where the respondents said they were recognized when given challenging tasks (mean score 4.26). In the goal setting theory, employees who are given specific and challenging tasks enhance their job performance when they are recognized.

Concerning the statement that there's a formal process for submitting new ideas in their institution, the respondents disagreed (mean score 2.99).They also disagreed on the statement that there was room for being creative in their institution (mean score 3.28). This is contrary to the findings of Gichohi (2014) where the respondents agreed with the statement "Staff having opportunity to exhibit creativity and innovation, promote, and develop adequate plans and schedules for the implementation of new ideas" (means score of 4.39).

The respondents also disagreed that they have been rewarded or recognized for being presenting a new idea (mean score 2.40). This is contrary to a study done by Gichohi (2014) where the respondents 
INTERNATIONAL JOURNAL OF ACADEMIC RESEARCH IN BUSINESS AND SOCIAL SCIENCES

Vol. 9, No. 3, March, 2019, E-ISSN: 2222-6990 @ 2019 HRMARS

agreed that their supervisor/manager rewards and recognizes employees who are creative and innovative in doing their job (mean score 3.42). The recognition of managers for the creative ideas without the use of scores or awards demonstrates the appreciation of the contributions of employees, by enhancing their intrinsic motivation, according to the studies of Alencar (2005), as cited by Pereira (2016).

A statement from the key informant contradicts. It states;

"Innovations and "new" ideas to improve processes are encouraged. These staffs are rewarded by being added responsibilities like being made in charges of units or departments. They are also sponsored for further trainings and conferences to improve their skills."

They disagreed on the statement that their suggestion to resolve problems or issues concerning work processes or patient related issues are taken into consideration (mean score 3.10). This is contrary to Gichohi (2014) where the respondents agreed on the statement "staff being regarded as a good source of creative and innovative ideas" (mean score 4.52). A statement from a key informant also contradicts this.

"We introduced a "gift mother-baby pack" to increase the number of hospital deliveries. This was after it was suggested by staffs working with expectant mothers suggested it. The number of women delivering in the hospital has since increased thanks to that suggestion"

The goal setting theory by Lock and Latham (2002) explains that innovative ideas may be changing or modifying certain processes and procedures improve institutions' efficiency and as a consequence, the performance of an entire organization improves.

\section{Discussion and Conclusion}

Pearson correlation tests were used to determine the extent to which performance management components within each category were related to employee productivity.

The study revealed that performance planning influences employee productivity positively and significantly $\left(r=.544^{* *}, P=.000\right)$. This leads to the rejection of the null hypothesis $\left(\mathrm{H}_{01}\right)$ and the acceptance of the alternative hypothesis $\left(\mathrm{H}_{1}\right)$. The study, therefore, concludes that performance planning has a significant positive influence on employee productivity in referral hospitals of Kiambu County. Performance planning has been identified by the literature as one of the key variables influencing employee productivity positively. A study by Poku (2013) in Ghana indicated that inclusion of all employees in planning influences employee productivity positively.

The results from this study also indicated that performance appraisal influences employee productivity and this influence is statistically significant $\left(r=.641^{* *}, P=.000\right)$. This leads to the rejection of the null hypothesis $\left(\mathrm{H}_{02}\right)$ and the acceptance of the alternative hypothesis $\left(\mathrm{H}_{2}\right)$. This is interpreted as that performance appraisal influences employee productivity positively in county referral facilities of Kiambu County. The findings in this study compare to another study done by Chaponda (2014) on survey of slum based non-governmental organizations in Nairobi that performance appraisal had helped to improve job performance.

The correlations analysis results of this study revealed that there is a positive and significant influence of giving feedback to employee productivity in County Referral Hospitals of Kiambu County $\left(r=.700^{* *}\right.$, P.000). This leads to the rejection of the null hypothesis $\left(\mathrm{H}_{03}\right)$ and the acceptance of the alternative 
hypothesis $\left(\mathrm{H}_{3}\right)$. The study then concludes that giving feedback influences employee productivity significantly. The findings in this study are similar in a study done by Kaymaz (2011) where it supported that individual constructive feedback is important in influencing employee productivity.

Finally the study also revealed that rewarding performance influences employee productivity positively and significantly $\left(r=.673^{* *} P=.000\right)$. This leads to the rejection of the null hypothesis $\left(\mathrm{H}_{04}\right)$ and the acceptance of the alternative hypothesis $\left(\mathrm{H}_{4}\right)$. The implication here is that rewarding performance enhances employee productivity. The findings of this study are similar to the one done by Ibrar, Owais (2015) where they concluded that there was a positive relationship between reward (extrinsic and intrinsic) and employees' job performance. In a study by Ricci (2016), she found a strong correlation between rewards and employee productivity $(r=.64, p<.001)$, such that the more aligned the rewards system were, the more likely the employees productivity increased.

In conclusion, the bivariate linear correlation analysis found out that giving feedback $\left(r=.700^{* *}\right.$, $P .000)$ has the strongest correlation with employee productivity compared to the other three variables rewarding performance $\left(r=.673^{* *} P=.000\right)$ appraisal $\left(r=.641^{* *}, P=.000\right)$ and finally planning $\left(r=.544^{* *}, P=.000\right)$.

A standard multiple regression analysis was conducted with all the four components (Planning, Appraisal, Feedback and Reward) entered into the analysis simultaneously. As seen in Table 5.1, the set of four components had a significant relationship with employee productivity $(F(4,222)=74.140$, $P=.000)$. The study further revealed that the four components explained $57.7 \%$ of the total variations in employees' performance $\left(R^{2}=.577, R^{2}\right.$ adjusted $\left.=570\right)$. The $R^{2}$ provides the proportion of variation in the dependent variable that is explained by the independent variables in the model. The coefficients in the regression model as shown in Table 5.2

Table 5.1 ANOVA $^{\mathrm{a}}$

Multiple Regression Model Validity

\begin{tabular}{|llllll|}
\hline Regression & 176.526 & 4 & 44.132 & 74.140 & $.000^{\mathrm{b}}$ \\
Residual & 129.168 & 218 & .595 & & \\
Total & 305.694 & 222 & & & \\
\hline
\end{tabular}

a. Dependent Variable Y(Productivity)

b. Predictors (Constant), $\mathrm{X}_{4}$ (Reward), $\mathrm{X}_{1}$ (Planning), $\mathrm{X}_{3}$ (Feedback), $\mathrm{X}_{2}$ (Appraisal)

Table 5.2 The Multiple Regression Model Summary ${ }^{b}$

\begin{tabular}{lllll} 
Model & $R$ & R Square & Adjusted R Square & Std. Error of the Estimate \\
1 & $.760^{\mathrm{a}}$ & .577 & .570 & .77152 \\
\hline
\end{tabular}

a. Predictors (Constant), Reward, Planning, Feedback, Appraisal

b. Dependent Variable Productivity 
The results of regression analysis in Table 5.2, indicates that $76.0 \%$ of the total variations in influence of performance management systems on employee productivity can be explained by the four factors under investigation in this study as represented by R-squared (.577). The remaining $24.0 \%$ of the variations can be explained by factors not included in this study. This means, therefore, that further research should be conducted to investigate other factors that contribute to employee productivity in county referral facilities of Kiambu County. The standard error of estimate .77152 shows the average deviation of the independent variables from the line of best fit.

The significance value is .000 which is less than .05 and thus the model is statistically significant in predicting how performance planning, performance appraisal, feedback on performance and reward are contributing to employee productivity. The regression output in Table 5.1, containing all the four variables in this study was found to be valid $\left(F_{(4,221)}=74.140, P<.001\right)$. This means that the four predictor variables in this study are good in explaining influence of performance management systems on employee productivity in referral hospitals of Kiambu County.

Multiple regression analysis was done to determine whether the performance management components (planning, appraisal, feedback and reward) were predictive of employee productivity. First, this analysis aimed to determine which of the four performance management system components was most predictive of employee productivity. Second, this analysis aimed to uncover which component most uniquely related to employee productivity.

This model is expressed as

$Y=b_{0}+b_{1} X_{1}+b_{2} X_{2}+b_{3} X_{3}+b_{4} X_{4}+\varepsilon$

Where $Y=$ Employee productivity, $\beta_{0}=$ Intercept (constant), $\beta_{1}, \beta_{2}, \beta_{3}, \beta_{4}=$ slope coefficients representing the influence of the associated independent variables with the dependent variable, $X_{1}$ $=$ performance planning, $X_{2}=$ performance appraisal, $X_{3}=$ feedback, $X_{4}=$ reward, $\varepsilon=$ Stochastic error term (extraneous).

Table 5.3 Multiple Regression Weights of variables

Coefficients $^{\mathrm{a}}$

\begin{tabular}{|c|c|c|c|c|c|c|}
\hline \multirow{2}{*}{\multicolumn{2}{|c|}{ Model }} & \multicolumn{2}{|c|}{$\begin{array}{l}\text { Unstandardized } \\
\text { Coefficients }\end{array}$} & \multirow{2}{*}{\multicolumn{2}{|c|}{\begin{tabular}{|l} 
Standardized \\
Coefficients \\
Beta \\
\end{tabular}}} & \multirow[b]{2}{*}{ Sig. } \\
\hline & & $\mathrm{B}$ & Std. Error & & & \\
\hline \multirow[t]{5}{*}{1} & (Constant) & .282 & .218 & & 1.294 & .197 \\
\hline & Planning & .130 & .092 & .100 & 1.415 & .159 \\
\hline & Appraisal & .129 & .101 & .117 & 1.277 & .203 \\
\hline & Feedback & .302 & .099 & .278 & 3.060 & .002 \\
\hline & Reward & .387 & .059 & .382 & 6.529 & .000 \\
\hline
\end{tabular}

a. Dependent Variable Employee productivity

Simultaneous multiple regression was conducted to investigate the best predictors of employee productivity. The study results of the multiple regressions in Table 5.3 indicate that all four 
components of performance management systems i.e. planning, appraisal, feedback on performance and reward of performance in predicting employee productivity.

In this simultaneous regression, the researcher wanted to test the combined effect of the four variables (planning, appraisal, feedback and reward) on employee productivity. This study revealed that as shown in the Table 5.3; performance planning $\left(\beta_{1}=.130, P=.159\right)$ and performance appraisal $\left(\beta_{2}=.129, P=.203\right)$, was found to be statistically insignificant in predicting employee productivity in county referral facilities of Kiambu County. The constant $\left(\beta_{0}\right)$ is statistically insignificant $\left(\beta_{0}=.282, P\right.$ $=.197)$. However, feedback on performance $\left(\beta_{3}=.302, P=.002\right)$, and reward of performance $\left(\beta_{4}=\right.$ $.387, P=.000$ ) were the strongest predictors of employee productivity in county referral facilities of Kiambu County when all the four variables are combined. Therefore, the more feedback and rewards the employees are given, the more the employees increased their productivity. The research suggests that organizations should implement these components into their performance management systems to increase employee productivity.

\section{Recommendation}

a. Managers should try to supply employees with adequate resources if they have to meet their targets. Clear, realistic goals that are set as a team enhance employee productivity.

b. Managers should have regular performance reviews with their employees with discussions so as to review past performance, and set targets for future performance.

c. Managers should try to provide regular feedback as it is desired by employees. Regular feedback corrects repetition of mistakes and keeps staff focused on what is required of them.

d. Reward system should be linked to the results of the appraisal which is just and fair. Therefore rewards should be an integral part of their system.

\section{Suggestions for Further Research}

i) This study was conducted in county referrals hospitals and may not be generalize to other tiers of the health facilities. Future studies may replicate this study to other lower tiers of health care system

ii) The study also revealed that planning, appraisal, feedback and reward are not the only factors that contribute to employee productivity. Future studies can look at other factors.

\section{References}

Aghajeri, M. \& Aghajeri, (2013) Investigating Factors Affecting Labor Productivity A Case Study in Eghtesad-e-Novin Bank, Iran European Online Journal of Natural and Social Sciences Vol.2 No.3

european-science.com/eojnss/article/download/2091/751Accessed 11/16/20171.55pm

Armstrong, M. \& Baron, A. (2004) Managing performance Performance Management in action. London. Chartered Institute of Personnel and Development.

Armstrong, M. (2006) Performance Management Key Strategies and Practical guidelines, 3rd ed. Bodmin, Cornwall MPG Books Itd.

Armstrong, M. (2009) Armstrong's handbook of performance management an evidence based guide to delivering high performance 
INTERNATIONAL JOURNAL OF ACADEMIC RESEARCH IN BUSINESS AND SOCIAL SCIENCES

Vol. 9, No. 3, March, 2019, E-ISSN: 222 2-6990 @ 2019 HRMARS

Armstrong, M. \& Taylor (2017) Armstrong's Handbook of Human Resource Management Practice

Bailey, R. \& Seifman, R. (2013) Applying the HRH Action Framework to Develop Sustainable Excellence in the Health Supply Chain Workforce, IntraHealth International http //www.capacityproject.org/framework/ (accessed June 30, 2017).

Balogun, M. J. (2003) Performance Management and Agency Governance for Africa Development The search for common cause on Excellence in the Public Service. Addis Ababa UNCEA.

Barmao, D.K. \& Nzuve, S.N.M. (2009) Impact of Training and Development on the Performance of the Employees of the General Service Unit -Kenya. University of Nairobi

Berg, J. M., Dutton, J. E. \& Wrzesniewski, A. (2013) Job crafting and meaningful work. Purpose and meaning in the workplace (pp. 81-104). Washington, DC American Psychological Association

Boateng, O.W., Owusu, V. (2014) The Effectiveness of Performance Appraisals in Measuring Employee Performance A Study of the First Capital Plus Limited. Public Policy and Administration ISSN 2224-5731(Paper) ISSN 2225-0972(Online) Vol.4, No.6. www.iiste.org10/25/2017 accesed at1.04pm

Chaponda, N. (2014) The Effect of Performance Appraisal on Employee Performance Appraisal on employee motivation A Survey of Slum Based Non-Governmental Organizations in Nairobi.erepo.usiu.ac.ke accessed on 30/08/2018at 3.39 PM

Davis, T. \& Landa M. (2011) A Contrary Look at performance Appraisal. Canadian Manager/Manager Canadian 3(2), 18-28

Department of Health UK (2016) The government's mandate to NHS England 2016-2017 A mandate from the government to NHS England April 2016 to March 2017 UK.

https //www.gov.uk/government/organisations/department-of-health accessed on $10 / 09 / 2017$ at $811 \mathrm{AM}$

Dieleman, M., Toonen J., Toure, H. \& Martineau, T. (2006) The match between motivation and performance management of health sector workers in Mali. https

//www.ncbi.nlm.nih.gov/pmc/articles/PMC1402315/ Accessed 10/07/2017 at 5 40a.m.

Farrel (2013) An investigation into Performance Appraisal effectiveness from the perception of Employees in an Irish Consumer Services Company http //trap.ncirl.ie/829/1/amiefarrell.pdf

Federal Relay Service (FSR) (2014) Performance Management Cycle Feedback is critical to improving performance, Office of Personnel Management.

Feldman, D.C. \& Thomas, W.H.N. (2009) Age, work experience, and the Psychological contract. Journal of organizational behavior Vol. 30 Issue 8

George, D. \& Mallery, P. (2003) SPSS for Windows step by step a simple guide and reference. 11.0 update. 4th edition. Boston Allyn \& Bacon.

Gibson, B. \& Cassar, G. (2005). Longitudinal Analysis of Relationships Between Planning and Performance in Small Firms. Small Business Economics, 25 (3), 207-222.http

//dx.doi.org/10.1007/s11187-003-6458-4

Gichohi, P. M. (2014) The Role of Employee Engagement in Revitalizing Creativity and Innovation at the Workplace A Survey of Selected Libraries in Meru County - Kenya" http

//digitalcommons.unl.edu/libphilprac/1171 
INTERNATIONAL JOURNAL OF ACADEMIC RESEARCH IN BUSINESS AND SOCIAL SCIENCES Vol. 9, No. 3, March, 2019, E-ISSN: 222 2-6990 @ 2019 HRMARS

GoK (2006) Results for Kenyans Capacity Building Program for Transforming the Public Service, Public Service Reform and Development Secretariat. Nairobi Government Printer, December.

GoK (2007) Kenya vision 2030 The National Economic and Social Council of Kenya. Nairobi, Kenya.

GoK (2008) Guide to the performance appraisal report. Forms GP 247 (revised 2008 and GP 247 b in the civil service and local authorities.

GoK (2010) Office of the Prime Minister. Performance contracting department report on evaluation of the performance of public agencies for the financial year 2008/2009 Nairobi Government Printer.

GoK (2010) Review of performance contracting in the public sector, Nairobi Government Printer. (Excerpts, September).

GoK (2013) Performance contracting guidelines FY 2013-2014 Division of performance contracting Health policy (2006) Performance Measurements in healthcare; Part II State of the Science findings by stage of the performance measurement process.

www.ncbi.nlm.nih.gov/pmc/articles/pmc2585424/extracted12/01/20121808hrs

Hope, K. (2011) The new public management Context and Practice in Africa. International Public Management Journal

http //www.ehow.com/about_5162691_definition-performance-measurement.html\# Definition of Performance Management Hall.

http//www.managementstudyguide.com/components-of-performance-managementsystem.htm

http //www.fao.org/sustainable-development-goals/goals/goal-3/en/8/3/2017

http//www.health.go.ke/wp-content/uploads/2015/09/HRH\%20Strategy\%202\%20Brief.pdf $8 / 3 / 2017$

http//www.kiambu.go.ke/about/health-access-and-nutrition Accessedbon 11/28/2017 at 9.00am

Hughes (2013) An Investigation Into Employee Engagement In Irelands Food Service Industry National College of Ireland

Institute of economic affairs (2015) Budget Guide Budget highlights 2015/2016. Nairobi, Kenya.

Ibrar, 0. (2015) The impact of reward on employee performance A case study of Malakand Private School. International letters of Social and humanistic SciencesISSN 2300-2697, Vol. 52

Iddagoda, Y.A., Henarath Opatha \& Kennedy Gunawardana (2015) Employee engagement conceptual clarification from existing confusion and towards an instrument that measures it. International Business Research; Vol. 9, No. 2; 2016 ISSN 1913-9004 E-ISSN 1913-9012 Published by Canadian Center of Science and Education.

http //ssrn.com/link/12th-ICBM-2015.html

Ismail, A., Hasan A. M. \& Norashikin S. H. (2011) Relationship between Performance Based Pay, Interactional Justice and Job Satisfaction A Mediating Model Approach Kuala Lumpur, Malaysia www.ccsenet.org/ijbm.International Journal of Business and Management. Vol. 6, No. 11;

Joint Learning initiative (2004) Human Resources for Health Overcoming the crisis. Cambridge Havard University Press. 
INTERNATIONAL JOURNAL OF ACADEMIC RESEARCH IN BUSINESS AND SOCIAL SCIENCES

Vol. 9, No. 3, March, 2019, E-ISSN: 222 2-6990 @ 2019 HRMARS

http //www.who.int/hrh/documents/JLi_hrh_report.pdf accessed on 4/09/2017 at 218 pm

Huprich, J. (2008) A brief introduction to performance management

http//ala-apa.org/newsletter/2008/06/15/a-brief-introduction-to-performance-

management/ accessed on 24/08/2017 at 6.47p.m.

Kamau, W.T. (2016) A study of the study of the performance of male nurses as care givers in selected public health care facilities in Kiambu County

Kiambu County (2015) Health at a glance. MoH, Nairobi.

http //www.healthpolicyproject.com.>Kiambureport.pdf Accessed 13/09/2017 at 5.09pm

Kibe, J.K., Abel A. \& Kilika J.M. (2013 Relationship Between Performance Appraisal And Teacher

Commitment In Kenya Case Study Of Public Schools In Nakuru. Kenyatta University.

Kim, Tae-Yeol, Alice H.Y. \& Michael J.C. (2009) Proactive Personality. Employee Creativity and Newcomer Outcomes A Longitudinal Study. Journal of Business Psychology, 24 93-103.

Kobia, M. and Mohammed, N. (2006) The Kenyan Experience with Performance Contracting Discussion paper, 28th AAPAM Annual Roundtable Conference, Arusha, Tanzania 4th - 8th December 2006.

Kothari, C. R. (2004) Research Design Qualitative, Quantitative, and Mixed Methods Approaches $4^{\text {th }}$ edition New Age International, New Delhi.

Krishnan, R. (2017) Challenges in Implementing a Performance Management System Enterprise

Risk Management Academy.

Kurtulus, K. (2011) Performance Feedback Individual based reflections and the effect on

motivation Business and Economics Research Journal Vol.2 No.4.www.berjournal.com

Latham, G. (2003) Goal setting A five step approach to behavior change organizational dynamics Vol. 32 NO3 pp. 309-318

http //bevhills.pbworks.com/f/Five-Step-Approach.pdf

Leong, C. S., (2014) Benefits from Increasing Salary, Employee Benefits and Rank for Promotion the Nursing Shortage in Macao Chinese Society. Universal Journal of Public Health 2(1) 10-16

Lewis, J.M. (2015) the politics and consequences of performance measurement; Policy and Society Journal vol.34 issues1.

Lichiello, P. \& Turnook B. (2009) Guidebook for performance Measurement.

Locke, E. and Latham (1990) A Theory of Goal Setting and Task Performance Englewood Cliffs, NJ Prentice-Hall https

//www.researchgate.net/publication/232501090_A_Theory_of_Goal_Setting_Task_Pe rformance accessed on 21/08/2017 648 a.m.

Locke, E. \& Latham, G. (2002) Building a practically useful theory of goal setting and task motivation American Psychologist

http//www.farmerhealth.org.au/wp-content/uploads/2016/12/Building-a-Practically-

Useful-Theory-of-Goal-Setting-and-Task-Motivation-A-35-Year-Odyssey.pdf. Accessed on 21/08/2017 704 am

Lutwama, G. W., Janetta H. R. \& Bethabile L.D. (2013) Assessing the implementation of performance management of health care workers in Uganda BMC Health services Research https //www.ncbi.nlm.nih.gov/pmc/articles/PMC3849262/\#B10 Accessed 10/07/2017 at 5 10a.m. 
INTERNATIONAL JOURNAL OF ACADEMIC RESEARCH IN BUSINESS AND SOCIAL SCIENCES

Vol. 9, No. 3, March, 2019, E-ISSN: 222 2-6990 @ 2019 HRMARS

Mansor, A. (2011) Determinants of performance management systems in South East Asia International Journal of Contemporary Research in Business Vol. 3 No 2 https//www.researchgate.net/publication/284545587_DETERMINANTS_OF_PERFORMANCE _MANAGEMENT_SYSTEM_IN_SOUTH_EAST_ASIA accessed on 16/7/2017 at 4 05pm.

Markus, L. (2004) Performance Management -Problems and Potential 12 key steps to ensure top performance from your staff. Centranum.

Mathaeur, I. and Imhoff I. (2006) Health Worker Motivation in Africa The role of non-financial incentives and Human resource tools. Human Resources for Health.

Maycock (2015) Managing employee reward implementing competency based pay as an alternative to seniority based pay Coventry, UK. International Journal of Advanced Research in Engineering \& Management (IJAREM).

Metawen, M. (2005) Problems with the implementation of performance measurement system in the public sector where performance is linked to pay; a literature review drawn from the U.K. Nice.

Ministry of Health (MOH) and Health Sector Reform Secretariat (2005) The National Health Sector Strategic Plan 1999-2004. Nairobi, Kenya.

Ministry of Health (MOH) (2006) Reversing the trends, The Second National Health Sector Strategic Plan of Kenya Annual Operational Plan 2 2006/07. Nairobi, Kenya.

Ministry of Health (MOH) (2014) Health Sector Human Resources Strategy 2014-2018. Nairobi, Kenya.

Ministry of Health (2014) Human Resources for Health Norms and Standards Guidelines for The Health Sector Required investments for equitable, and adequate capacity to deliver the Kenya Essential Package for Health

Ministry of Health (MOH) (2016) Health Sector Working Group Report Medium Term Expenditure Framework for the period 2017-18 to 2019-20 Nairobi, Kenya.

Ministry of Health (MOH) (2016) Kenya Reproductive Maternal, Newborn Child and Adolescent Health (RMNHCAH) Investment Framework. Nairobi, Kenya.

Ministry of Health (MOH) (2016) User guide on Employee relations for the health sector in

Kenya Towards a cohesive workforce for quality service delivery. Nairobi, Kenya.

Nayak and Achar (2014) An evaluation of performance management system in health care organization- a case study India for management studies and research., India.

Njeru Beth and Harriet Kidombo (2013) The Role Of Performance Appraisal System On Job Performance In The Public Sector A Case Of Civil Servants In Kirinyaga Central District

Mugenda, O. M. and Mugenda, A. G. (2003) Research Methods Quantitative and Qualitative Approaches. Nairobi African Centre for Technology Studies Press.

Mumbi, J. (2012) Employee perception of the performance appraisal process in Telkom Kenya Limited. University of Nairobi Jomo Kenyatta Memorial Library

Mutinda, M. (2017) An Overview of Performance Contracting in Kenya's Public Sector Benefits and Challenges. Imperial Journal of Interdisciplinary Research (IJIR) Vol-3, Issue-1ISSN 2454-1362, http //www.onlinejournal.in Imperial Journal of Interdisciplinary Research (IJIR) accessed 24 August 2017 at 917 am. 
INTERNATIONAL JOURNAL OF ACADEMIC RESEARCH IN BUSINESS AND SOCIAL SCIENCES

Vol. 9, No. 3, March, 2019, E-ISSN: 222 2-6990 @ 2019 HRMARS

Moriones, A.B., Jose E.G. \& Maia, G. (2004) Is Seniority Based Pay Used as a Motivation Device? Evidence from Plant Level Data. Germany IZA Discusion Paper No 1321

Nankervis (2006) Performance Management in the Workplace. Performance Management Institute https //www.peoplestreme.com/what-is-performance-management accessed 20/7/2017 at 9 04am

Nassazi, A. (2013) The Effect of Training on Employee Performance European Journal of Business and Management ISSN 2222-1905 (Paper) ISSN 2222-2839 (Online) Vol.5, No.4, www.iiste.org

Najafi, L., Yadollah, H., Sudabeh V. \& Abdolhosein, P. (2010) Performance Appraisal and Its Effect on Employees Motivation and Job Promotion. Australian Journal of Basic and Applied Sciences Vol 4 No. 9

Ndubai, R.E. (2011) Performance contacts in the management of the Public Service in Kenya.

Obwaya, A. K. and Florence M. (2010) Effectiveness of Employee Performance Management System at Kenya National Audit Office. University of Nairobi.

O'Connor, R. and Neuman V. (2006) Payment by Results or payment by outcome? The history of measuring medicine; Journal of the Royal Society of Medicine Vol. 99pp226-231.

Olusanya, S.O. \& Suleiman A. (2012) Effective Planning and Organisational Productivity. A Case Study of Sterling Bank Nigeria PIc. IOSR Journal of Humanities and Social Science (JHSS)

Oluwabusola, J. (2015) Managing employee reward Implementing competency based pay as an alternative to seniority based pay International Journal of Advance Research in Engineering and Management Vol.01

Oosterom, (2007) The road ahead for public service delivery Delivering on the customer promise. Public Sector Research Center PriceWaterHouseCoopers.

Https//www.pwc.com/gx/en/psrc/pdf/the_road_ahead_for_public_service_delivery.pdf accessed on 22/9/2017 at 9 28am

OPM/PTSD (Office of The Prime Minister/Public Transformation Sector Department) (2010) Public sector transformation Strategy; From Reform to Transformation 2010-14, Nairobi PM/PTSD.

Paile, N. (2012) Staff perceptions of the implementation of a performance management and development system Father Smangaliso Mkhatswa case study

Performance Contracts Steering Committee, Kenya (2004) Sensitization/ Training Manual on Performance Contracts in the Public Service.

Pereira João Antônio \& Gomes Roberto Sbragia (2016) Creativity and Innovation Performance at the Industry Level an Empirical Study in Brazilian Firms. International Association for Management of Technology IAMOT 2016 Conference Proceedings

Poku, D. K. (2013) The Effect of Strategic Planning on the Performance and operations of the Agricultural Development Bank. Case study of African Development Bank Ghana.

Poll, H. (2015) New Interact Report Many Leaders Shrink from Straight Talk with Employees.

Preker, A., Kate, T. \& Marko, V. (2008) Scaling Up Health Professional Education Opportunities and Challenges for Africa, Paper prepared for the Task Force for Scaling Up Education and Training for Health Workers, Global Health Workforce Alliance, World Bank, Washington, D.C.

Reason \& Rigor (2017) How Conceptual Frameworks Guide Research. Second edition, Los Angeles, CA SAGE, Sutton. 
INTERNATIONAL JOURNAL OF ACADEMIC RESEARCH IN BUSINESS AND SOCIAL SCIENCES

Vol. 9, No. 3, March, 2019, E-ISSN: 222 2-6990 @ 2019 HRMARS

Regoniel, P. (2015) Conceptual Framework A Step by Step Guide on How to Make One.In SimplyEducate.Me.Retrieved

http //simplyeducate.me/2015/01/05/conceptual-framework-guide/

Republic of Kenya (2007) Kenya Vision 2030, Nairobi; Republic of Kenya.

Ricci, L., Howard, T. \& Megumi, H. (2016) The Impact of Performance Management System Characteristics on Perceived Effectiveness of the System and Engagement. San Jose State University SJSU Scholar Works. https //scholarworks.sjsu.edu/etd_theses/4702

Rono, J. (2002) The impact of the structural adjustment programmes on Kenyan Society. Journal of Social Development in Africa Vol. 17 No.1

Scheffler, R., Chris B.M., Brent D.F., Mario R.D \& Alexander S.P. (2009) Estimates of Health care professional's shortages in Sub Saharan Africa by 2015. Health affairs USA.

http //content.healthaffairs.org/content/28/5/w849.full.html Accessed 18/09/2017 4 03p.m.

Smith, P, Elias M., Irene P. \& Sheila L. (2009) Introduction in performance measurement for health systems improvement; experience, challenges and prospects. European Observatory on Health System Policies.

Shikanda, E. W. \& Bichanga W. O. (2011) Effects of Organizational Culture on Innovation in Services Industry A Case Study of Postal Corporation of Kenya .European Journal of Business and Management www.iiste.org ISSN 2222-1905 (Paper) ISSN 2222-2839 (Online) Vol 3, No.3

Uma, S. N. (2013) A Study on Training Importance for Employees of their Successful Performance in the Organization International Journal of Science and Research (IJSR) ISSN (Online) 23197064 Vol.2 Issue 11 https //www.ijsr.net/archive/v2i11/MDIwMTMzNjE=.pdf

Uzodike, O. \& Chitakunye (2014) Public sector performance management in Africa Reforms policies and strategies. Mediterranean Journal of Social Sciences Vol. 5 No. 26 https//www.researchgate.net/publication/306118591_Public_Sector_Performance_Manag ement_in_Africa_Reforms_Policies_and_Strategies accessed 3/09/2017 at 430 pm

Were, M. (2005) Understanding Reform Process in Kenya Global development www.gdn.int.>GDN_funded_paper Accessed 6/08/2017 at 4 34pm

WHO (2000) The World Health Report; Health Systems Improving performance, Switzerland. http //www.who.int/whr/2000/en/whr00_en.pdf. Accessed10/9/2017 at 11.23am

WHO (2006) World Health Report Working together for health, Geneva. http //www.who.int/hrh/whr06/en/ accessed 20/9/2017 at 1234 pm.

WHO (2007) Everybody's business strengthening health systems to improve health outcomes WHOs framework for action. WHO press, Switzerland.

WHO (2008) Service delivery Toolkit on monitoring health system strengthening. http//www.who.int/healthinfo/statistics/toolkit_hss/EN_PDF_Toolkit_HSS_ServiceDelivery. pdf Accessed 22/9/2017 at 811 am.

WHO (2009) Human Resources for Health Toolkit on monitoring health systems strengthening http //www.who.int/healthinfo/statistics/toolkit_hss/EN_PDF_Toolkit_HSS_HumanResources_oc t08.pdf accessed on 21/9/2017 
INTERNATIONAL JOURNAL OF ACADEMIC RESEARCH IN BUSINESS AND SOCIAL SCIENCES

Vol. 9, No. 3, March, 2019, E-ISSN: 2222-6990 C 2019 HRMARS

WHO (2014) Paying for Performance in Health Care Implications for health system performance and accountability. New York Open University press.

WHO (2015) Trends in maternal mortality 1990 to 2015 Estimates by WHO, UNICEF, UNFPA, World Bank Group and the United Nations Population Division http//www.who.int/reproductivehealth/publications/monitoring/maternal-mortality2015/en/ accessed on 8/82017 at 3 09pm www.yourhealth.gov.au/internet/yourhealth/publishing.nsf/content/ExpertPanelsupplementary Annexure. www.gabriellubale.com@2012.www.slideshare.net/GabrielLubable/perfromancemanagement-framework-in-public-service-of-kenya. Accessed on 3/5/2014 a 6.34 pm.

WHO (2016) Global Strategy on Human Resources for Health workforce 2030 WHO Switzerland.

Xanthopoulou, B., Demerouti, \& Schaufeli (2007) The role of personal resources in the job demandsresources model. International journal of stress management, 14(2), 121.

Yamoah, E. E. (2014) Reward Systems and Teachers' performance Evidence from Ghana.Canadian Social Science Vol.9 No5.

Zekeng, E. (2016) Health care Systems in Sub-Saharan Africa Focusing on community based delivery of health services and the development of local research institutes. Peace and progress-The United Nations University graduate student journal Vol. 3(1) pp 44-49

\section{Carolyn Akinyi Owino (Corresponding Author)}

Department of Health Systems Management, Kenya Methodist University, Nairobi, Kenya

Email: muhcarol@gmail.com 